The Geographical Journal of Nepal

Vol. 10: 89-104, 2017

Central Department of Geography,

Tribhuvan University, Kathmandu, Nepal

\title{
Tourism development and economic and socio-cultural consequences in Everest Region
}

\author{
Dhyanendra Bahadur Rai \\ Central Department of Geography, Tribhuvan University, Kirtipur, Kathmandu, Nepal \\ Email:dbrrai@yahoo.com
}

Being a mountainous country, Nepal is one of the destinations of tourist. Everest Region is one of the major destination trekking and mountaineering tourism and ranks second after Annapurna Region in term of number of tourists visiting different regions of Nepal. The number of tourist visiting this region increased from only 1406 in 1971/72 to 37124 in 2014. Such a growth of tourism has several socio-economic and cultural consequences. This paper discusses the consequences of tourism in Everest Region. Informations were collected along the trekking routes from Lukla to Dinboche through focus group discussion, key informant interview and tourism business survey. The results indicate that the number of hotels and lodges in many settlements along the trekking route has increased tremendously. The main base of economic life of Sherpa community has been changed from agro-pastoralism to tourism based business. The level of employment and income of local people has improved. However, tourism has undermined Sherpa culture by introducing new values and lifestyles influencing from westerners, eroded the central role of religion and traditional value in Sherpa community. For the younger generation the tourist and their norms of behavior and patterns of consumption can be seductive. This is the symptom of losing of cultural value of Sherpa community and world identity of Sherpa in the future.

Keywords: Everest Region; Sherpa; trekking and mountaineering tourism; consequences; hotel and lodges 


\section{Introduction}

Mountain tourism holds about a quarter of the global tourist industry. In Nepal, trekking and mountaineering tourism keeps great value in tourism industry which ranks in the second position in terms of tourist arrival by purpose of visit, annually with a total of 97185 tourists (MOCTCA, 2015). Some fluctuations nevertheless, the proportion of tourist visiting in Nepal with the purpose of trekking and mountaineering has risen steadily from 0.1 percent in 1966 to11.8 in 1980, 15.7 percent in 1990, 25.6 percent in 2000,11.6 percent in 2010, and 12.30 percent in 2014. Tourism contributes 4.8 percent in foreign earning exchange and it shares 2.0 percent in Gross Domestic Products. Annually 544 million US dollar is earned from tourism sector (MOCTCA, 2015).

Trekking and mountaineering in Nepal is mostly confined in three major areas (Annapurna, Everest and Langtang/Helambu) which occupy 87 percent of the total trekking and mountaineering tourist arriving in Nepal (MOCTCA, 2013).Incidentally, these three areas are associated with National Parks and Conservation Areas. Annapurna Region comprises 58.61 percent of the trekking and mountaineering tourism followed by Everset Region (23.34 percent) and Langtang- Helambu Region (8.18 percent) (MOCTCA, 2015). Everest Region (Sagarmatha National Park) is known as the second popular trekking destination in Nepal after Annapurna Region. Tourist visiting in the Everest Region has increased from 1406 in 1971/72 to 37124 in 2014/15 (record of Sagarmatha National Park at Jorsale). Such an increase in trekking and mountaineering tourism in the area has several socio-economic and cultural consequences. This paper discusses the development of trekking and mountaineering tourism in Khumbu Region and its consequences along the main trekking route from Luckla to Dinboche.

\section{Study area}

The Everest Region liesin between $86^{\circ} 31^{\prime}-86^{\circ} 58^{\prime}$ East longitude and $27^{\circ} 47^{\prime}-28^{\circ} 71^{\prime}$ North Latitude. It is located about $90 \mathrm{~km}$ north east from Kathmandu. Everest Region consists of three sub-region - Khumbu (Namche and Khumjung Village Development Committees) in the north, Pharak (Charikharka) in the middle and Solu in the south. This study covers part of Khumbu and Pharak area along the major trekking route from Lukla to Dinboche. 


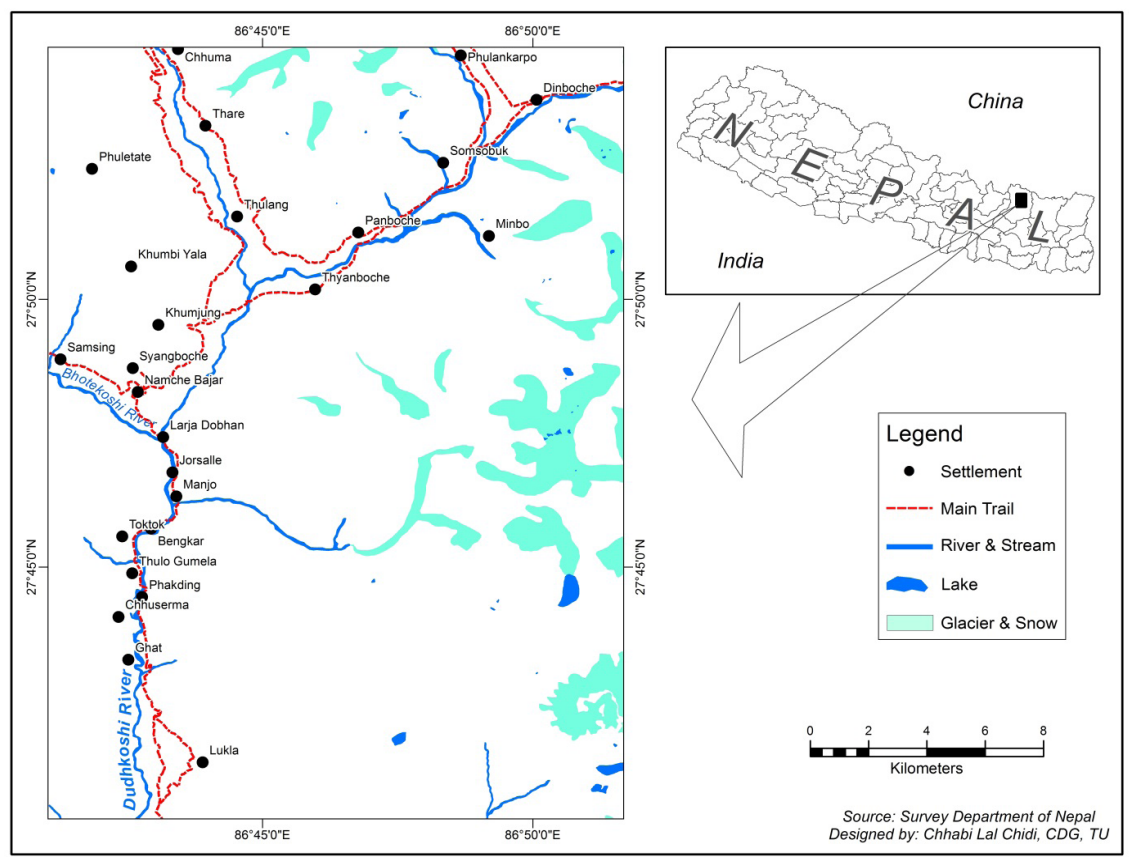

Figure 1. Location of study area

The main trekking route starts from Lukla, an airstrip and descent to Dudhkoshi River. Several large and small settlements are appeared along the route. The major settlements of the routes are Ghat, Phakding, Toktok, Benkar, Manjo, Jorsale, Namche, Khumjung, Panboche and Dinboche (Figure 1).

\section{Method and materials}

This study is basically based on primary data. Primary data were collected using checklist through key informant interview, in-depth interview and group discussions. Transect walk and direct observation from Lukla to Dinboche was carried out. Information observed during the fieldwork was recorded in topographic maps and notebooks. Key informant interview and focus group discussion were carried out in different settlements along the route. The size of the focus group ranged from six to ten people. Mostly, the main sources of information were local entrepreneur related with tourism business. Indepth interview were conducted with ten local business persons for understanding their views about present development and also to cross-check information collected through other different sources. School teachers, social workers, women and porters were participated in the FGD. They represented different caste/ethnic groups, occupations, 
Dhyanendra Bahadur Rai / The Geographical Journal of Nepal Vol. 10: 89-104, 2017

age and sex. Similarly, a total of seven key informants were interviewed. For KII, local school teachers, social workers, politicians, members of community organizations and VDC officials were selected.

\section{Results and discussion}

\section{Development of tourism in Everest Region}

The successful ascent of Mt. Everest $(8,848 \mathrm{~m})$ the highest peak on the globe made by Tenzing Norgay Sherpa and Sir Edmound Hillary on 29 May, 1953 popularized Khumbu as the fertile and prospective place for trekking and mountaineering. Everest Region is one of the tourist attractions area because i) there are many Himalayan peaks including Mt. Everest, the highest peak of the world, ii) the area lies within Sagarmatha National Park with high biodiversity and iii) the area is designated as World Heritage Site.

The number of tourist visiting this area increased from only 1406 in 1971/72 to 11314 in 1990/91 and 16921 in 1996/97. Figure 2 shows the number of tourist visiting this region from 1998 to 2015 . It shows that there has been tremendous growth in the number of tourist between 1998 and 2015. However strong annual variation is observed. There was rapid decline in the number of tourist visiting this area in the years - 2002, 2005, 2015. The number of tourist visiting this area remained quite low between 2001 and 2007. It was mainly due to Maoist insurgency in the country. Likewise, the decline in 2015 is mainly due to the damages of tourism related service infrastructures caused by massive earthquake of April, 2015. Most trekkers and mountaineers come from western Europe, UK, Germany, France and Netherlands.

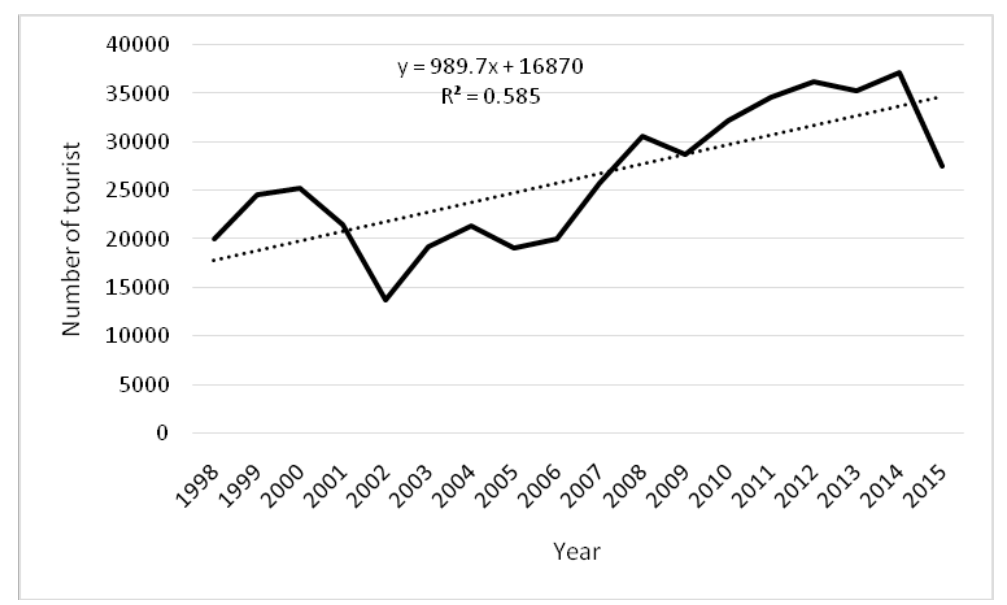

Figure 2. Number of tourist visited Khumbu by year (source: Sagarmatha National Park at Jorsale, 2016)

||92 || 
Another characteristics of the flow of tourist as in this area is seasonality. Figure 3 shows that there are two peaks - one in April and another one in October. Nearly 92 percent tourist visit the area in two seasons - September to November (57 percent) and March to May (35\%). In other months the number of tourists remains less than 800 . Such seasonality in the flow was also reported in the study of Sharma (1998).

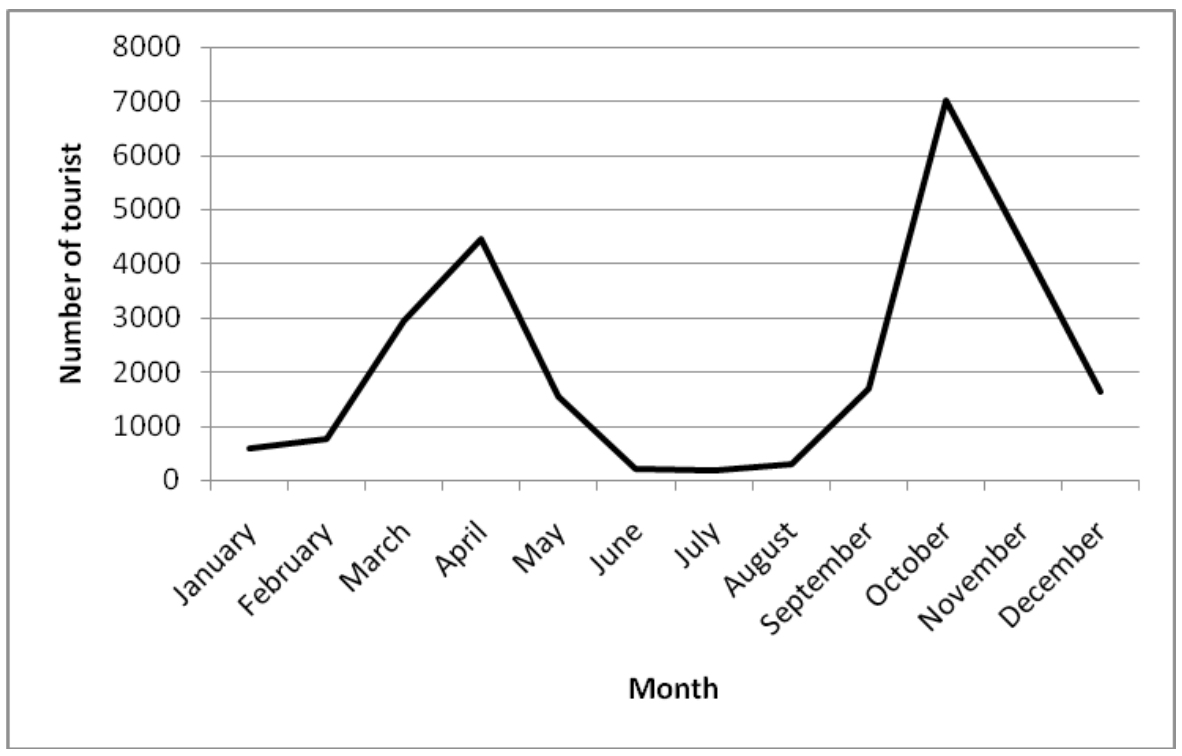

Figure 3. Average number of tourist visited Khumbu by month ( 1998-2015)

Many historical events, political change as well as administrative decisions and events being in the country have affected the real situation of tourist related activities in Everest Region. First climbing of Mount Everest, ending political autonomy of Khumbu after establishing Panchayat System, nationalization of forest, designation of Sagarmatha National Park, declaration of SNP as a World Heritage Site,Visit Nepal 1998 Programme, entrance of private airlines service to Lukla, Golden jubilee of Sagarmatha ascending etc are the main events that influenced to the positive development of tourism in Khumbu (Table 1). Construction of airstrip in Lukla, hospital in Lukla, Khumjung School, hydro-electricity project and facilities of communication (cell phone) etc. are important infrastructures which directly supported to the growth of tourism in Khumbu (Garrard et al., 2012; Garrard et al., 2016). Dig Cho GLOF in Dudhkosi River, ten years 
Dhyanendra Bahadur Rai / The Geographical Journal of Nepal Vol. 10: 89-104, 2017

conflict from 1995-2005 in the country and destructive massive earthquake of April, 2015 are some of the events which resulted the decline in tourist visiting the area.

Table 1. Major historical events in the Everest Region related to tourism development

\begin{tabular}{|l|l|}
\hline Year & Important actions/events that influenced to Khumbu tourism \\
\hline 1951 & Exposed Nepal in the world after overthrew of Rana Rule \\
\hline 1953 & First ascent of Mt. Everest by Tenzing Norgay Sherpa and Edmond Hilary \\
\hline 1964 & Lukla airstrip built in 1964 that facilitated tourist arrival in Khumbu \\
\hline 1973 & First lodge, hospital and school established in this region \\
\hline 1979 & $\begin{array}{l}\text { Establishment of Khumbu Region as the Sagarmatha National Park (SNP) } \\
\text { in 1976 }\end{array}$ \\
\hline 1985 & Declaration of SNP as a World Heritage Site by UNESCO in 1979 \\
\hline 1994 & A hydroelectric project, 600 KW completed \\
\hline 2001 & $\begin{array}{l}\text { Ten years conflict started in } 1995 \text { and declared emergency in } 2001 \text { which } \\
\text { resulted decline in visiting tourist. }\end{array}$ \\
\hline 2006 & End of ten years conflict and rejuvenation of tourism activities \\
\hline 2015 & Destructive Gorkha Earthquake 2015 \\
\hline
\end{tabular}

Source: Field survey, 2010 and 2015.

\section{Consequences of the growth of tourism}

\section{Growth of hotels and lodges}

The first hotel was opened in 1971 in Namche Bazar for the purpose of tourism. By the end of 1979, there were 17 hotels and lodges in this route. Tourism activities increased rapidly in Khumbu Region in the decade of 1980s and 1990s. As a result the number of hotel and lodgesalso increased significantly. There are 282 delightful hotels and lodges excluding small hotel and tea shops along the major trekking routes from Lukla to Everest Base Camp serving the tourists visiting this area. About 90 percent hotels and lodges are operated by Sherpa community and rest of the hotels and lodges by Rai and Tamang arriving from outer area. According to the available data, the number of hotels and lodges increased from 1979 to 1999 with more than six times (from 17 to 108 in this route). Similarly, the growth rate has remained 1.66 percent from 1999 to 2009 in this ten years period. 
The section from Lukla to Dinboche is more important for tourism activities because most of the stays of tourist lie in this section. In the total of Everest Region, more than 80 percent hotels and lodges are operated here. There are ten major settlements locating hotels and lodges in this route. Namche, Lukla, Khumjung, Phakding, Dinboche, Manjo, Panboche, Benkar are notable among them. Namche is the most popular tourist center of Khumbu located at 3400 meter altitude which covers about 18 percent hotels and lodges along this route followed by Lukla (14 percent) and Khumjung (12 percent). Namche is also a permanent market place. In Namche, most of the people have adopted tourist business especially hotels and lodges. Agricultural activities also happen in small quantityin Namche. Namche is the old settlement of upper Khumbu area inhabited by Sherpa community. It is the gateway to Mount Everest base-camp (Gurung, 1980). The second largest settlement is Lukla where an airstrip all round the year for Everest Region has been operated. Lukla occupies 14 percent hotels and lodges of this region (Table 2).

Table 2. Hotels and lodges along the route (Lukla to Dinboche)

\begin{tabular}{|l|l|l|l|l|l|}
\hline SN & Settlement & $1979 *$ & $1999^{* *}$ & $2009^{* *}$ & $2012 * * *$ \\
\hline 1 & Lukla & na & 25 & 34 & 39 \\
\hline 2 & Ghat & na & 4 & 6 & 14 \\
\hline 3 & Phakding & na & 7 & 16 & 29 \\
\hline 4 & Bengkar & na & 2 & 4 & 23 \\
\hline 5 & Manjo & na & 5 & 10 & 25 \\
\hline 6 & Jorsalle & 3 & 3 & 5 & 15 \\
\hline 7 & Namche Bazar & 10 & 35 & 45 & 51 \\
\hline 8 & Khumjung & 1 & 9 & 25 & 35 \\
\hline 9 & Panboche & 3 & 4 & 14 & 24 \\
\hline 10 & Dinboche & na & 14 & 21 & 27 \\
\hline & Total & 17 & 108 & 180 & 282 \\
\hline
\end{tabular}

Source: *Stevens, 1996; ** Field survey, 2010 and *** Rai, 2013.

Figure 4 shows the growth in the number of hotels and lodges in major settlements located along the main trekking and mountaineering route. There has been increase in the number of hotels and lodges in all these settlements. 


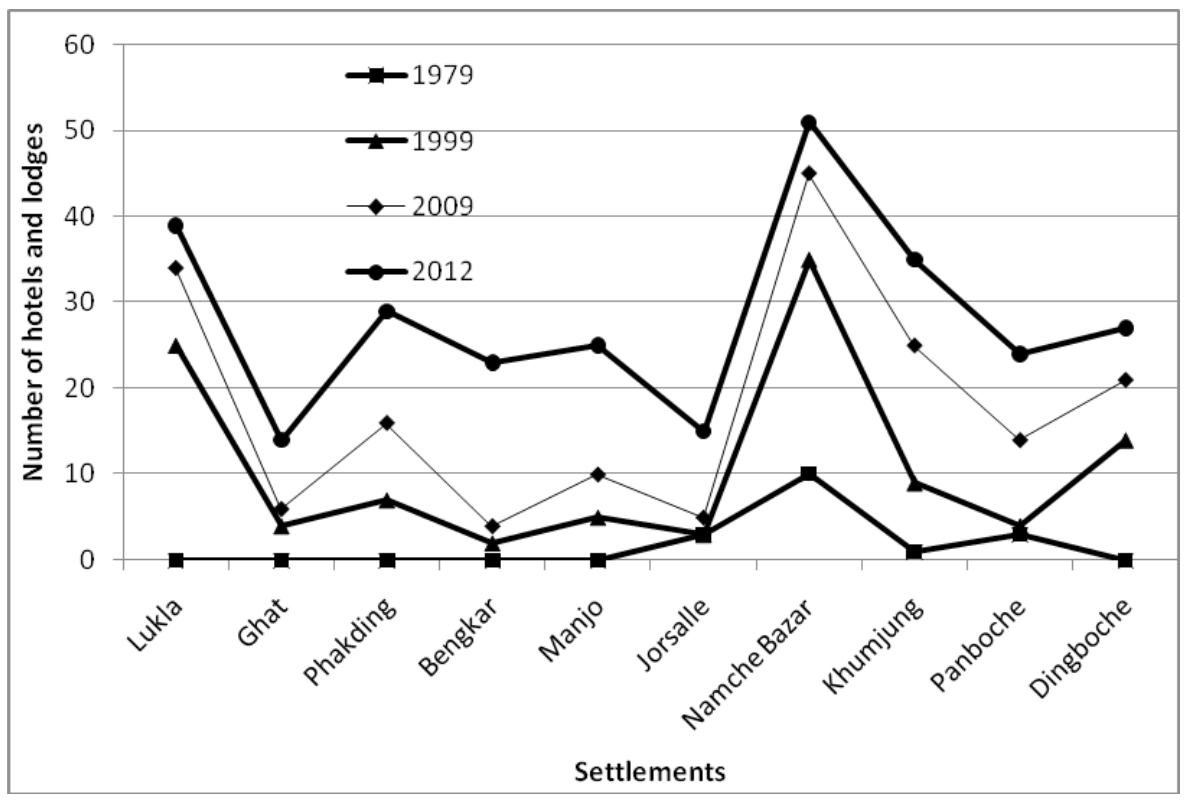

Figure 4. Number of hotels and lodges in different periods

\section{Economy}

According to the oral traditions, the Sherpas migrated and settled in the high homeland that they call Khumbu more than four centuries ago (Stevens, 1996). Khumbu was the Trans-Himalayan trade route before long time (Furer-Haimendorf, 1975). In the 1950s and early 1960s, it was far less developed and could only be reached by foot or on the back of an animal. The major option of livelihood was based on agro-pastoral activities.

After the growth of tourism in this area, their economy is mainly based on tourism business. The majority of people living in the region are now engaged in the tourism business in one form or another since 1960s. Overall, most people consider their livelihoods to have improved in recent years. Employment opportunities in the region have increased significantly due to an increase in tourism-related businesses such as hotels, lodges, trekking and climbing expeditions. Some now even own and operate Kathmandu-based trekking companies that organize mountain journeys throughout Nepal including Khumbu. Porters, guides, high altitude guides, cooks at the hotels, and jobs in retail shops have become a major sources of employment in the region. Because of the rapid growth of tourism in the region, occupations are shifting from ||96" 
agro-pastoralism to tourism as more and more people establish lodges, campgrounds, hotels, and pack animal services.

Most of the Sherpa households have adopted income-generating activities based on tourism. Sherpas are employed in trekking and mountaineering activities as group leaders (sirdars), porters and cooks as a part of trekking groups or mountaineering expeditions. While due to their growing positive reputation Sherpa men are most likely to find trekking or mountaineering job easily, participation of women have been relatively small though some women are employed as kitchen or camp crews or as packstock drivers. As Sherpas of Khumbu continue to discover better opportunities brought about by tourism, they have started considering a job of porter inferior due to low pay. So, in recent years most of the porters in Khumbu are from outside the area; they are mainly the Sherpas, Rais and Tamangs from lower areas.

Since the late 1960s, tourism based businesses and entrepreneurship has also mushroomed in the region. Numerous lodges have been built to cater to the trekkers and mountaineers. Gradually, tourism based services have established at major touristic centers like Lukla and Namche. Stores selling food, souvenirs and selling or renting trekking or mountaineering equipments are also quite popular. At the beginning, Sherpas used to merely modify their own houses or herding huts as lodges, nowadays there are specially built lodges with modern facilities. However, the cost of building a lodge is increasing because of the high cost of land and rising cost of materials especially wood.

Table3. Economic consequences of tourism development in Everest Region

\begin{tabular}{|c|c|}
\hline \multicolumn{2}{|c|}{ Nature of impacts } \\
\hline Positive & Negative \\
\hline $\begin{array}{l}\text { - Diversification in income source } \\
\text { - Entrepreneurship development in local people } \\
\text { - Improvement in the life standard } \\
\text { - Infrastructure development } \\
\text { - Beginning of high value cash crops } \\
\text { - Growth of market towns and settlements }\end{array}$ & $\begin{array}{l}\text { - Seasonal unemployment } \\
\text { - Lack of labor in agricultural } \\
\text { sector } \\
\text { - Over dependent in imported } \\
\text { goods } \\
\text { - Growing expensiveness } \\
\text { - Inflation and dependency }\end{array}$ \\
\hline
\end{tabular}

Source: Field survey, 2010 and 2016.

Running a lodge in Khumbu is a highly lucrative business as informed by participants of FGD and key informants related with hotel business in Namche, a 
popular lodge can earn as much as $\$ 10,000$ a year, and most lodges earn at least $\$ 20000$ annually. That provides enough funds to purchase supplies at the local weekly market or Kathmandu and to hire wage labor. A committee of local lodge owners has been formed to monitor prices of Khumbu lodges to avoid any price conflicts. Though employment as a part of expedition is seasonal, most of the Sherpas are employed throughout the year by the mountaineering and trekking agencies based in Kathmandu. Also the income earned during the tourism season is sufficient for the rest of the year for sustaining their livelihood. A woman, proprietor of a hotel in Panboche expresses her views thus when I asked about the earning situation from hotel business;

Operating hotel/lodge is our main occupation from twenty years ago. It
is our main base of livelihood. We earned about six/seven million NRs in
one season. This amount becomes sufficient for running household and
for education of children. I am satisfied with this business.

Trekking seasons occur during the period of important agricultural works like plantation and harvesting. The absence of so many men during part of the year has had lifestyle impacts on their families. Though women have always played the fundamental role in the cultivation of land, subsistence activities, and family decision making as well. Some works like field preparation in early spring and hay cutting during late summer season are performed by men due to the off-season of tourist. In this circumstance, most of the works and responsibilities have to be accomplished by women as the in-charge of home. It has increased women empowerment and whole local community as well in the Everest Region. Seasonal labors for carrying out hotel-lodge business and cultivation from lower areas of Solukhumbu, Okhaldhunga and Khotang have become main basis of workers in the region. The worker earns Rs. 1200-15000 in a month.

In some areas in Sagarmatha National Park tourism related activities are emerging as more important than traditional agro-pastoralism. New economic opportunities opened up due to tourism have impacted land use along major trails. High value /cash crops such as vegetable, off-season vegetable, fruit farming have been started in this area. Dependency of local economies on outside forces has increased with all its negative effects. Seasonal unemployment, lack of labor in agricultural sector, over dependent in imported goods, growing expensiveness, and inflation and dependency are some of the major negative consequences of tourism in Everest Region.

\section{Socio-culture}

Tourism is today one of the world's most significant sources of cultural contact, creating situations of both enormous cross-cultural communication and conflict (Lama, 1997). ||98 | 
Tourists not only bring money to region; but they also carry along with them a strong and visible life-style (Kunwar, 2006). It causes the interaction of peoples from diverse parts of the world, fostering the diffusion of ideas, values, technology, consumer tastes, and lifestyles. Such interactions may weaken local culture and lead to a variety of types of socio-cultural change. In the context of Everest Region, cultural imitation has increased due to tourism. This is reflected in dress, language, food and festival. The impact is seen in more influential in especially new generation of this area. Due to this cause, it has increased artificialness, socio-cultural conflict and conflict in the society. Sometimes there happen criminal activities too.

Table 4. Socio-cultural consequences of tourism development in Everest Region

\begin{tabular}{|c|c|}
\hline \multicolumn{2}{|c|}{ Nature of impacts } \\
\hline Positive & Negative \\
\hline $\begin{array}{l}\text { - Cultural exchange between local people } \\
\text { and tourists } \\
\text { Preservation of local culture and tradition } \\
\text { being realized } \\
\text { - Growth in sense of pride of cultural } \\
\text { heritages } \\
\text { - Exposure of the local people in the world } \\
\text { - Growing awareness and educational } \\
\text { expansion } \\
\text { Empowerment of local community } \\
\text { especially women } \\
\text { Diffusion of ideas, values, technology, } \\
\text { consumer tastes, and lifestyles }\end{array}$ & $\begin{array}{l}\text { - Imitation of Western culture } \\
\text { - Growing artificialness in the } \\
\text { community } \\
\text { - Socio-cultural and inter- } \\
\text { generational conflicts } \\
\text { - Local cultural values and } \\
\text { traditions are loosing } \\
\text { - Commercialization of art and } \\
\text { local heritage } \\
\text { - Social tension between those } \\
\text { benefitting from tourism and not } \\
\text { benefitting } \\
\text { - Work burden to women }\end{array}$ \\
\hline
\end{tabular}

Source: Field survey, 2010 and 2016.

The arrival of tourists in another people's homeland always brings with it the possibility of cultural frictions between hosts and their new (and often uninvited) guests. There is also the commoditization of culture dial takes place when everyday crafts are sought after for souvenirs and locally meaningful ceremonies and festivals become tourist attractions. This can lead to art and cultural performances losing their meaning for local residents (Stevens, 1993). In some cases both art and ceremonies may even be deliberately altered to fit tourist tastes.

Tourism has changed lifestyles of Khumbu people in other ways. In the past before tourism, there used to be a distinctive seasonality in economic activities by the 
altitudinal locations of settlement in the region. After the autumn crop harvest most families used to leave the region and traveled and traded in the warmer, lower-altitude regions to the south until it was time to return for spring planting. This migration no longer takes place, in part because of the new demands of the autumn and spring tourist seasons and in part because new affluence from tourism has replaced the earlier winter barter-trade journeys. A new pattern is now emerging, with many families using some of their tourism income to make mid-winter journeys in the coldest months to Kathmandu for shopping, pilgrimage, and visiting city-based friends, relatives, and children. Older people especially value the opportunity to spend a few months in the warmer capital.

There have also been tourism-related changes in a number of facets of local lifestyles including diet and clothing which are related to new affluence and to new, tourism-introduced consumer fashions. Sugar, chocolate, coffee, and beer, for example have become parts of Sherpa life. Tourism income has also enabled families to purchase more tea and coffee, processed foods such as noodles manufactured in other parts of Nepal, and larger amounts of lower-altitude grown grains including rice, wheat, maize, pulse and millet. A lot of meat (pork, buffalo, mutton and chicken) is consumed which is supplied by porter carrying on back from lower parts of Khumbu. Clothing styles are also changing which are observed vividly along the route. Men almost universally have adopted tourist clothing, giving up their wool cloaks for Western-style shirts and pants. Sun glasses are also very popular. Women have maintained more traditional styles of dress, although some unmarried young women have taken to wearing jeans and other tourist clothing. And no visitor to Khumbu today can help but be struck by the popularity of Western consumer electronics. Many families have radios, television and tape players, and there is an abundance of personal stereos. For many Sherpas listening to Western, Nepali, and Tibetan music and Nepali news broadcasts on these devices has become a part of daily life, even something that is often done while hiking along the mountain trails. In this respect, an old local Sherpa people of Namche says that,

Gradually, we are losing our old traditions and culture now-a-days. The language is going to extinct in the near future. The new generation doesn't understand Sherpa language but they are perfect in English language. The youths, both boy and girl feels uneasy wearing Sherpa dress.

All Sherpa people attending in focus group discussion agreed that the traditional Sherpa culture has been influenced and sometimes replaced by western culture and technologies, such that many people have partially abandoned their traditional value, dress, religious rituals and functions. Many Sherpas, for example, resent tourists' lack || 100 || 
of respect for Buddhism. They are angered by tourists' violation of the most basic local religious customs, which require the chorten shrines, prayer wheels, and walls of carved prayer stones always be passed or circumambulated with the religious monument kept to the right. Doing so signifies respect for Buddhism, while passing to the left demonstrates the opposite.

Sherpas continue to be proud of their traditions and continue to observe Buddhism. An interview with senior local Sherpa people informed that new wealth has been used for restoration of temples, building of new shrines, and expansion of monasteries which have all worked in strengthening their cultural ties. Cultural pride and value has increased among local people. They have spirit of preservation of local culture and tradition that is found during survey as suggested by Kunwar (2006). However, there have been some instances when tourism is seen to hamper the traditional culture. Inability of tourist to maintain respect in the shrines and photographing without consideration has often angered local people. Tourism has influenced Sherpas to send their children to school and also to learn English. Sherpas have been able to send their children to good school through their tourism earnings. Locals have greater access to health facilities due to establishment of infrastructure for health by government as well as charitable donation from foreign visitors.

Tourism has also created a potentially socially-disruptive social problem by encouraging emigration. On the one hand it may have prevented possible large-scale migration from the region during the late 1960s and early 1970s, when the decline of the trade with Tibet undermined many households' economies. Yet while the opportunities in tourism have probably slowed total out-migration from Khumbu over the past 25 years, some talented and bright men have migrated to Kathmandu. Several of these men work in the offices of the Kathmandu-based trekking agencies and others have opened their own trekking agencies and other businesses. Out-migration may well increase in the future, for many families are now using their new wealth from tourism and support from tourist sponsors to send their children to boarding schools in Kathmandu and an increasing number of children are now studying abroad. Local people are concerned that many of these children may not return to the region.

A more important social impact of tourism development is revealed in the increasing social tensions between those benefitting from tourism and not benefitting, and between big stakeholders (big hoteliers) and small stakeholders (small teashop owners) and local entrepreneurs and newcomers. Such social tensions are experienced in this region especially in taking benefits and using resources. A newly established hotel 
owner of Rai community of Phakdin who is immigrated from lower Solu expressed his view such;

I established this hotel four years ago. Before starting hotel business, I used to engage in trekking in the Everest route. I have understood all kinds of practices and know to local people. Despite so, we have to face various problems in this place especially in terms of resource use.

\section{Conclusion}

The Everest Region is the home of outstanding mountain scenery and the renowned Sherpa people in the world. It is more of native and a little bit culture and known for its unique natural and cultural landscape characteristics. Today, Sagarmatha National Park is one of the most important mountain tourism destinations in Nepal, as well as in the world. The number of tourist visiting the area has increased from hundred in the late 1960 s to more than 37,000/year in 2014. Tourism is of critical importance to the region and represents the main source of income along the trekking route of Everest Region especially from Lukla to Dinboche in Sherpa community. Most households have converted their household economies in order to participate in the new emerging tourist economy. This major economic change has been accompanied by social and cultural change. Income level of local Sherpa people has been increased significantly. Not only this, it has diversified in the income sources of local people too. Not only on communities located on the main trekking routes but even on villages that are located out of main tracks. Traditional social and economic aspects of especially Sherpa people of this region have been greatly influenced by the surrounding mountain environment and towering Sagarmatha. Similarly tourism is making local people more dependent leaving other profession like agro-pastoralism. The impact of tourism on society and culture begin to appear as the economic dependency on tourism grows and the demonstration effects and commercialization of culture become more evident. There are not all negative impacts of such tourism in this region. Growing awareness towards environmental issues, economic upliftment of the local people, women empowerment, sense of pride of cultural heritages etc. are positive impact of trekking/mountaineering tourism in the Everest Region. Despite being critical of tourism, we have to use it as a window through wihich we can spread our cultural values far and wide. The income that people earn from this sector should be used in different sustainable income generating 
Dhyanendra Bahadur Rai / The Geographical Journal of Nepal Vol. 10: 89-104, 2017

activities giving due care in maintaining the region's unique ecological diversity and ecosystem.

\section{References:}

Brower, B. A. (1987). Livestock and landscape: The Sherpa pastoral system in Sagarmatha (Mt. Everest) National Park, Nepal.Ph.D. dissertation.Department of Geography. University of California, Berkley.

Byers, A. C. (1997). Landscape change in the Sagarmatha (Mt. Everest) National Park, Khumbu, Nepal, Himalayan Research Bulletin XVII: 31-41.22.34

District Development Committee (2063). Solukhumbu periodic district development plan, 2058/059-2063/64), DDC Solukhumbu.

Fisher, J. F. (1990). Sherpas: Reflections on change in Himalayan Nepal. Berkley. Los Angeles, Oxford; University of California of Press.

Fürer-Haimendorf, C. von (1975). Himalayan traders: Life in highland Nepal, London: John Murray.

Garrard, R., Kohler, T., Price, M. F., Byers, A. C., Sherpa, A. R. \& Maharjan, G. R. (2016). Land use and land cover change in Sagarmatha National Park, a World Heritage Site in the Himalayas of Eastern Nepal, Mountain Research and Development MRD Vol 36 No 3 Aug 2016: 299-310

Garrard, R., Kohler, T., Wiesmann, U., Price, M. F., Byers, A. C. \& Sherpa, A. R. (2012). An ever-changing place: interpreting landscape change in Sagarmatha National Park, Management \& Policy Issues. Volume 4, Number 2, December.

Gurung, H. (1980). Vignettes of Nepal. Sajha Prakasan, Kathmandu.

Kunwar, R. R. (2006). Tourists and tourism: Science and industry interface. International School of Tourism and Hotel management. Kathmandu.

Lama, S. (1997). Sherpa culture and mountain tourism in Khumburegion, Unpublished Master's Thesis, Central Department of Sociology/Anthropology: T. U. Kiritipur, Nepal.

MOCTCA. (2013). Nepal tourism statistics-2012. Government of Nepal, Ministry of Culture, Tourism \& Civil Aviation, Planning \& Evaluation Division Statistical Section Singha Durbar, Nepal 
Dhyanendra Bahadur Rai / The Geographical Journal of Nepal Vol. 10: 89-104, 2017

MOCTCA. (2015). Nepal tourism statistics-2014. Government of Nepal, Ministry of Culture, Tourism \& Civil Aviation, Planning \& Evaluation Division Statistical Section. Singha Durbar, Nepal

Rai, S. (2013). Trekking tourism and development: Along the trekking route of Manebhanjang to Namche Bazar, Unpublished Master's Thesis, Central Department of Geography: T. U. Kiritipur, Nepal.

Rogers, P. (1997). Tourism development and change in the Sagarmatha National Park and environment, Newsletter Nepal Tourism Board. April, 2011. Vol. 12/ Issues 116.

Sharma. P. (1998). Approaches to Promoting mountain tourism for local development: Experience from Nepal. The Himalayan Review (tourism special issue).vol. $X X I X$.

Stevens S. F. (1996). Claiming the high ground: Sherpas, subsistence and environmental change in the Highest Himalaya, Oakland, CA: University of California Press.

Stevens, S. F. (1993). Tourism, change and continuity in the Mount Everest Region, Nepal, Geographical Review, Vol. 83, No. 4. (Oct., 1993), pp. 410-427. 